\title{
PENGARUH KOMISARIS INDEPENDEN DAN KOMITE AUDIT TERHADAP KINERJA KEUANGAN PADA PERUSAHAAN PERBANKAN YANG TERDAFTAR DI BURSA EFEK INDONESIA
}

\author{
Yan Christin Br. Sembiring ${ }^{1}$ \\ Afni Eliana Saragih ${ }^{2}$ \\ ${ }^{1}$ Dosen Program Studi Akuntansi Universitas Katolik Santo Thomas. \\ yanchristin11@gmail.com \\ ${ }^{2}$ Dosen Program Studi Akuntansi Universitas Katolik Santo Thomas. \\ afni.elianasaragih@gmail.com
}

\begin{abstract}
Abstrak
Tujuan penelitian ini adalah untuk menguji secara empiris pengaruh komisaris independen (KI) dan komite audit (KA) terhadap kinerja keuangan pada perusahaan perbankan yang terdaftar di Bursa Efek Indonesia secara simultan dan parsial. Populasi dalam penelitian ini diambil dari perusahaan perbankan yang terdaftar di Bursa Efek Indonesia selama tahun 2016-2017 yaitu 43 perusahaan. Adapun metode yang digunakan adalah metode purposive sample dimana perusahaan yang masuk dalam kriteria adalah berjumlah 31 perusahaan. Akan tetapi, membuang data outlier sebanyak 7 perusahaan, sehingga unit analisisnya adalah 55 perusahaan. Hasil analisis menunjukkan bahwa datadata yang digunakan dalam penelitian ini telah memenuhi uji asumsi klasik, yang meliputi: tidak terjadi gejala multikolinearitas, tidak terdapat autokorelasi, tidak terjadi heteroskedastisitas, dan data terdistribusi normal. Dari hasil analisis regresi linier berganda menunjukkan bahwa variabel KI dan KA tidak berpengaruh signifikan terhadap kinerja keuangan secara simultan dan parsial.
\end{abstract}

Kata kunci : Komisaris Independen (KI), Komite Audit (KA), dan Kinerja Keuangan

\section{PENDAHULUAN}

Penerapan Good Corporate Governance (GCG) semakin gencar dilakukan semenjak munculnya skandal akuntansi seperti kasus Enron, dan Worldcom yang melibatkan akuntan. Di Indonesia juga telah tercatat beberapa kasus yang melibatkan persoalan laporan keuangan seperti PT. Lippo dan PT. Kimia Farma yang berawal dari terdeteksi adanya manipulasi (Boediono, 2005). Penerapan GCG yang dilakukan dengan efektif dapat meningkatkan efisiensi dan pertumbuhan ekonomi sekaligus kepercayaan investor (OECD, 2004). Peningkatan penerapan GCG menjadi kebutuhan yang mendasar sebab investasi akan mengikuti sektor 
yang mengadopsi standar tata kelola efisien (OECD, 2004). Perusahaan yang menerapkan GCG seharusnya memiliki kinerja keuangan yang baik.

Kinerja keuangan perusahaan merupakan salah satu ukuran keberhasilan atas pelaksanaan fungsi-fungsi keuangan dalam perusahaan. Ukuran kinerja perusahaan yang baik di awali dengan adanya kepercayaan dari investor terhadap suatu perusahaan bahwa dana yang mereka investasikan dalam kondisi yang aman dan diharapkan akan memberikan return yang baik pula.

Komisaris independen adalah anggota dewan komisaris yang tidak memiliki hubungan keuangan, kepengurusan, kepemilikan saham, dan/hubungan keluarga dengan anggota dewan komisaris lainnya, direksi dan/pemegang saham pengendali atau hubungan lain yang dapat mempengaruhi kemampuannya untuk bertindak independen. Hubungan antara komisaris independen dan kinerja perbankan juga didukung oleh perspektif bahwa dengan adanya komisaris independen diharapkan dapat memberikan fungsi pengawasan terhadap perusahaan secara objektif dan independen.

Komite audit adalah salah satu komite yang dibentuk oleh dewan komisaris dan bertanggung jawab kepada dewan komisaris dengan tugas dan tanggung jawab utama untuk memastikan prinsip-prinsip good corporate governance. Dalam mendukung terciptanya tata kelola bank yang baik setiap perbankan yang telah tercatat pada bursa harus memiliki komite audit.

Beberapa penelitian tentang pengaruh GCG menunjukkan hasil yang berbeda-beda. Hal ini dikarenakan indikator tiap variabel untuk mengukur GCG dan kinerja keuangan berbeda-beda. Arifani (2013) dalam penelitiannya menunjukkan bahwa GCG yang diukur dengan komisaris independen berpengaruh positif signifikan terhadap kinerja keuangan. Akan tetapi, hal ini tidak sejalan dengan penelitian Tertius (2015) komisaris independen berpengaruh negatif terhadap kinerja keuangan, sedangkan penelitian Veno (2015) yang menunjukkan bahwa komisaris independen tidak berpengaruh signifikan terhadap kinerja keuangan. Komisaris independen merupakan anggota dewan komisaris yang berasal dari luar perusahaan yang bertujuan untuk memberikan perlindungan terhadap pemegang saham minoritas dalam sebuah perusahaan.

Hartono (2014) dalam penelitiannya menunjukkan bahwa GCG yang diukur dengan komite audit tidak berpengaruh terhadap kinerja keuangan. Hal ini berbeda dengan Arifani (2013) dan Veno (2015). Masing-masing penelitian mereka menunjukkan bahwa komite audit 
berpengaruh positif signifikan terhadap kinerja keuangan. Komite audit merupakan perpanjangan tangan dari dewan komisaris dalam melakukan kontrol dan monitoring terhadap dewan direksi.

Berdasarkan bukti empiris yang menghubungkan antara GCG yang diukur dengan komisaris independen dan komite audit terhadap kinerja keuangan masih menunjukkan hasil yang berbeda-beda, maka tujuan khusus penelitian ini menguji bagaimana pengaruh GCG tersebut terhadap kinerja keuangan terutama pada sektor perbankan di Bursa Efek Indonesia (BEI) periode 2016-2017. Pemilihan perusahaan perbankan adalah karena perbankan secara universal merupakan sebuah industri regulator dan bank memiliki akses ke jaringan pengaman pemerintah. Oleh karena itu, bank harus memiliki GCG yang kuat.

Urgensi penelitian ini adalah penerapan GCG pada saat ini bukan lagi sekedar kewajiban, namun telah menjadi kebutuhan bagi setiap perusahaan dan organisasi. GCG diperlukan untuk memberikan kemajuan terhadap kinerja suatu perusahaan, menjadikan perusahaan berumur panjang dan bisa dipercaya.

Berdasarkan uraian tersebut, maka peneliti tertarik untuk melakukan penelitian lebih lanjut dengan judul penelitian "Pengaruh Komisaris Independen dan Komite Audit Terhadap Kinerja Keuangan Pada Perusahaan Perbankan yang Terdaftar di Bursa Efek Indonesia"

\section{TELAAH TEORI}

\section{Agency Theory}

Teori agensi sangat sulit untuk diterapkan dan memilki banyak kendala serta masih belum memadai, sehingga diperlukan suatu konsep yang lebih jelas mengenai perlindungan terhadap para stakeholders. Konsep tersebut harus berhubungan dengan masalah-masalah konflik kepentingan dan biaya-biaya agensi yang timbul, sehingga berkembang suatu konsep baru yang memperhatikan dan mengatur kepentingankepentingan para pihak terkait dengan kepemilikan dan pengoperasional (stakeholders) suatu perusahaan, yaitu konsep good corporate governance.

\section{Kinerja Keuangan}

Kinerja keuangan merupakan suatu gambaran tentang kondisi keuangan suatu perusahaan yang dianalisis dengan alat-alat analisis keuangan, sehingga dapat diketahui mengenai baik buruknya keadaan keuangan suatu perusahaan yang mencerminkan prestasi kerja dalam 
periode tertentu. Pengukuran kinerja keuangan perusahaan dilakukan untuk melakukan perbaikan dan pengendalian atas kegiatan operasional perusahaan agar dapat bersaing dengan perusahaan lain. Kinerja keuangan perusahaan dapat diukur dengan menggunakan rasio keuangan. Investor melakukan penanaman modal salah satunya dengan melihat rasio profitabilitas. Rasio profitabilitas yang digunakan dalam penelitian ini menggunakan Return on Asset (ROA) karena dapat memberikan gambaran tingkat pengembalian keuntungan yang dapat diperoleh investor atas investasinya (Prasinta, 2012).

\section{Good Corporate Governance (GCG)}

Dalam buku (Brigham dan Erhardt, 2005), GCG didefinisikan sebagai seperangkat aturan dan prosedur yang menjamin manajer untuk menerapkan prinsip-prinsip manajemen berbasis nilai. GCG didefinisikan oleh IICG (Indonesian Institute of Corporate Governance) sebagai proses dan struktur yang diterapkan dalam menjalankan perusahaan dengan tujuan utama meningatkan nilai pemegang saham dalam jangka panjang dan tetap memperhatikan kepentingan stakeholders yang lain.

Berdasarkan Surat Keputusan Menteri BUMN Kep-117/MMBU/2002 tanggal 1 Agustus 2002 pasal 3 tentang penerapan praktik corporate governance meliputi lima prinsip yaitu transparency, independency, accountability, responsibility, dan fairness.

\section{Komisaris Independen}

Komisaris independen bertujuan untuk penyeimbang pengambilan keputusan dewan komisaris. Proporsi dewan komisaris yang berasal dari luar perusahaan atau komisaris independen juga mempengaruhi kinerja perusahaan yang bertindak sebagai penengah dalam perselisihan yang terjadi di antara para manajer internal dan mengawasi kebijakan manajemen serta memberikan nasihat kepada manajemen. Komisaris independen merupakan posisi terbaik untuk melaksanakan fungsi monitoring agar tercipta perusahaan yang good corporate governance. Menurut Peraturan Pencatatan nomor IA tentang Ketentuan Umum Pencatatan Efek bersifat Ekuitas di Bursa yaitu jumlah komisaris independen minimum 30\% dari jumlah seluruh anggota komisaris.

\section{Komite Audit}

Pembentukan komite audit oleh perusahaan-perusahaan publik sudah banyak di lakukan di berbagai negara termasuk Indonesia. Seiring 
dengan menguatnya tuntutan agar perusahaan lebih transparan dan reliable mengenai kinerjanya, peran komite audit menjadi semakin penting. Surat Edaran Bapepam No. SE-03/PM/2000 menyatakan bahwa komite audit pada perusahaan publik Indonesia terdiri dari sedikitnya tiga orang anggota dan diketuai oleh komisaris independen perusahaan dengan dua orang yang berasal dari eksternal perusahaan yang independen. Hal tersebut menggambarkan bahwa semakin banyak jumlah anggota komite audit yang independen dalam suatu perusahaan diharapkan akan meningkatkan pengawasan yang dilakukan, sehingga kinerja perusahaan dan integritas laporan keuangan dapat menjadi lebih baik.

\section{Kerangka Konsep}

Kerangka konsep dibentuk untuk menunjukkan pengaruh variabel independen yaitu KI dan KA terhadap variabel dependen yaitu kinerja keuangan seperti gambar berikut:

Gambar 2.1. Kerangka Konsep

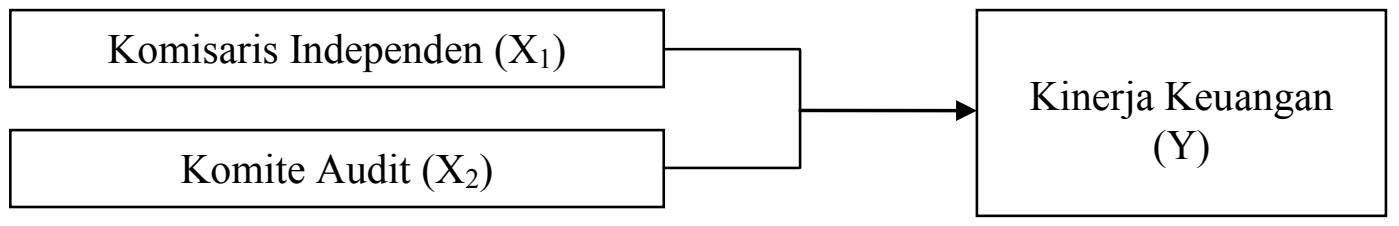

\section{Hipotesis}

Hipotesis merupakan jawaban sementara atas permasalahan dalam objek penelitian. Berdasarkan perumusan masalah, maka hipotesis penelitian ini adalah:

a. Komisaris independen berpengaruh terhadap kinerja keuangan pada perusahaan perbankan yang terdaftar di Bursa Efek Indonesia.

b. Komite audit berpengaruh terhadap kinerja keuangan pada perusahaan perbankan yang terdaftar di Bursa Efek Indonesia.

c. Komisaris independen dan komite audit berpengaruh terhadap kinerja keuangan pada perusahaan perbankan yang terdaftar di Bursa Efek Indonesia.

\section{METODE PENELITIAN \\ Populasi dan Sampel}

Populasi dalam penelitian ini adalah seluruh perusahaan perbankan yang terdaftar di BEI selama tahun 2016-2017. Teknik penentuan sampel dalam penelitian ini yaitu menggunakan metode purposive sampling 
dengan tujuan mendapatkan sampel yang representatif. Purposive sampling (sampling bertujuan) adalah metode pengambilan sampel berdasarkan suatu kriteria tertentu, kriteria yang digunakan dapat berdasarkan perimbangan (judgement) atau berdasarkan kuota tertentu (Erlina, 2011).

Dalam penelitian ini, kriteria perusahaan perbankan yang dijadikan sampel penelitian adalah:

a. Perusahaan perbankan yang listing selama tahun penelitian.

b. Perusahaan perbankan yang menyampaikan laporan keuangan pada tahun penelitian yang telah diaudit.

c. Perusahaan perbankan yang menggunakan mata uang rupiah.

d. Perusahaan perbankan yang tidak menghasilkan laba negatif selama tahun penelitian.

Populasi dalam penelitian ini terdiri dari 43 perusahaan perbankan. Populasi yang memenuhi kriteria untuk menjadi sampel berjumlah 31 perusahaan dengan 62 unit analisis (21x3 tahun). Akan tetapi, membuang data outlier sebanyak 7 perusahaan, sehingga unit analisisnya adalah 55 perusahaan.

\section{Operasionalisasi Variabel}

Operasionalisasi variabel merupakan batasan pokok pembahasan yang akan diteliti. Variabel yang diteliti dalam penelitian ini adalah:

Komisaris independen adalah anggota dewan komisaris yang berasal dari luar pemegang saham perusahaan. Proporsi komisaris independen diukur dengan persentase jumlah komisaris independen dibagi dengan jumlah anggota dewan komisaris (Sekaredi, 2011).

Komite audit adalah komite yang dibentuk oleh dewan komisaris untuk melakukan tugas pengawasan pengelolaan perusahaan. Dalam penelitian ini variabel ukuran komite audit ini diukur berdasarkan jumlah komite audit yang terdapat pada profil perusahaan (Sekaredi, 2011).

Dalam penelitian ini variabel dependen adalah kinerja keuangan yang diproksikan dengan ROA dihitung dengan cara mengurangkan laba bersih setelah pajak kemudian dibagi dengan total aset. Kinerja keuangan dirumuskan sebagai berikut (Syamsuddin, 2009):

Laba Bersih Setelah Pajak

$\mathrm{ROA}=$

Total Aset 


\section{Teknik Analisis Data}

Penelitian ini menggunakan metode analisis regresi linear berganda yang bertujuan untuk mengukur kekuatan asosiasi (hubungan) linear antara dua variabel atau lebih.

Adapun model yang digunakan dari regresi linear berganda yaitu:

$$
\mathrm{Y}=\mathbf{a}+\mathbf{b} 1 \mathrm{X} 1+\mathrm{b} 2 \mathrm{X} 2+\mathrm{e}
$$

Dimana:

$$
\begin{array}{ll}
\mathrm{Y} & =\text { ROA } \\
\mathrm{X} 1 & =\text { Komisaris Independen } \\
\mathrm{X} 2 & =\text { Komite Audit } \\
\mathrm{a} & =\text { Konstanta } \\
\mathrm{b} 1, \mathrm{~b} 2 & =\text { Koefisien Regresi } \\
\mathrm{e} & =\text { Variabel Pengganggu }
\end{array}
$$

\section{HASIL PENELITIAN DAN PEMBAHASAN}

\section{Uji Asumsi Klasik}

Model regresi yang baik adalah distribusi data masing-masing variabelnya normal atau mendekati normal. Pengujian normalitas dapat dilakukan dengan grafik histogram dan uji Kolmogorov - Smirnov (K-S). Jika histogram berbentuk seperti lonceng, tidak menyimpang maka data terdistribusi normal. Apabila signifikansi uji K-S $>0,05$ maka data terdistribusi normal. Hasil olah data dapat dilihat dari tabel berikut ini:

Tabel 1 Hasil Uji Kolmogorov-Smirnov Sebelum Membuang Data Outlier One-Sample Kolmogorov-Smirnov Test

\begin{tabular}{|ll|r|}
\hline & & $\begin{array}{r}\text { Unstandardiz } \\
\text { ed Residual }\end{array}$ \\
\hline N & Mean & 62 \\
Normal Parameters & $\mathrm{a}, \mathrm{b}$ &, 0000000 \\
& Std. Deviation &, 00883548 \\
Most Extreme Differences & Absolute &, 228 \\
& Positive &, 228 \\
& Negative &,- 156 \\
Kolmogorov-Smirnov $Z$ & & 1,798 \\
Asymp. Sig. (2-tailed) & &, 003 \\
\hline
\end{tabular}

a. Test distribution is Normal.

b. Calculated from data.

Sumber Hasil Penelitian, 2019 (data diolah SPSS) 
Dari tabel tersebut terlihat bahwa nilai signifikansi uji K-S adalah sebesar $0,003<0,05$ maka data terdistribusi tidak normal. Salah satu cara mengatasinya ada membuang data outlier atau data ekstrem. Setelah membuang data outlier tersebut, data diuji kembali dengan hasil sebagai berikut.

Tabel 2 Hasil Uji Kolmogorov-Smirnov Setelah Membuang Data Outlier One-Sample Kolmogorov-Smirnov Test

\begin{tabular}{|ll|r|}
\hline & & $\begin{array}{r}\text { Unstandardiz } \\
\text { ed Residual }\end{array}$ \\
\hline N & & 55 \\
Normal Parameters ${ }^{\mathrm{a}, \mathrm{b}}$ & Mean &, 0000000 \\
& Std. Deviation &, 00833525 \\
Most Extreme Differences & Absolute &, 174 \\
& Positive &, 174 \\
& Negative &,- 118 \\
Kolmogorov-Smirnov $Z$ & & 1,287 \\
Asymp. Sig. (2-tailed) & &, 073 \\
\hline
\end{tabular}

a. Test distribution is Normal.

b. Calculated from data.

Sumber Hasil Penelitian, 2019 (data diolah SPSS)

Dari tabel 2 terlihat bahwa nilai signifikansi uji K-S adalah sebesar $0,073>0,05$ maka data terdistribusi normal.

Regresi yang baik adalah regresi dengan tidak adanya gejala korelasi yang kuat antara variabel bebasnya. Multikolinearitas adalah situasi adanya korelasi antara variabel-variabel independen antara yang satu dengan yang lainnya. Metode yang digunakan untuk mendeteksi multikolinearitas dalam penelitian ini adalah tolerance - Variance Inflector Factor (VIF). Multikolinearitas terjadi apabila nilai VIF $\geq 10$ dan nilai tolerance $\leq 0,10$ (Ghozali, 2016). Hasil olah data dapat dilihat dari tabel berikut ini:

\section{Tabel 3 Hasil Uji Multikolinearitas}

\begin{tabular}{|c|c|c|c|c|c|c|c|c|}
\hline \multicolumn{9}{|c|}{ Coefficients $^{a}$} \\
\hline \multirow{2}{*}{\multicolumn{2}{|c|}{ Model }} & \multicolumn{2}{|c|}{ Unstandardized Coefficients } & \multirow{2}{*}{$\begin{array}{c}\begin{array}{c}\text { Standardized } \\
\text { Coefficients }\end{array} \\
\text { Beta }\end{array}$} & \multirow[b]{2}{*}{$\mathrm{t}$} & \multirow[b]{2}{*}{ Sig. } & \multicolumn{2}{|c|}{ Collinearity Statistics } \\
\hline & & $B$ & Std. Error & & & & Tolerance & VIF \\
\hline \multirow[t]{3}{*}{1} & (Constant) & ,017 & ,007 & & 2,319 & 024 & & \\
\hline & $\mathrm{KI}$ & ,003 & ,010 & 037 & ,265 & ,792 & ,939 & 1,065 \\
\hline & $\mathrm{KA}$ &,- 002 & ,002 &,- 168 & $-1,193$ & ,238 & ,939 & 1,065 \\
\hline
\end{tabular}

a. Dependent Variable: ROA

Sumber Hasil Penelitian, 2019 (data diolah SPSS) 
Dari Tabel 3 menunjukkan hasil perhitungan nilai tolerance tidak ada variabel independen yang memiliki nilai tolerance yang kurang dari 0,10 yang berarti tidak ada korelasi antarvariabel independen yang nilainya lebih dari $95 \%$. Hasil perhitungan nilai VIF juga menunjukkan hal yang sama tidak ada satu variabel independen yang memiliki nilai VIF lebih dari 10. Jadi dapat disimpulkan bahwa tidak ada multikolinearitas antarvariabel independen dalam model regresi.

Menurut Ghozali (2016) uji autokorelasi bertujuan menguji apakah dalam suatu model regresi linear ada korelasi antara kesalahan pengganggu pada periode $\mathrm{t}$ dengan kesalahan pada periode $\mathrm{t}_{-1}$ (sebelumnya). Jika terjadi korelasi, maka dinamakan ada masalah autokorelasi. Autokorelasi muncul karena observasi yang berurutan sepanjang waktu berkaitan satu sama lain. Masalah ini timbul karena residual (kesalahan pengganggu) tidak bebas dari satu observasi ke observasi lainnya. Hal ini sering ditemukan pada data runtut waktu atau time series karena "gangguan" pada individu atau kelompok cenderung mempengaruhi individu atau kelompok pada periode berikutnya. Model regresi yang baik adalah regresi yang bebas dari autokorelasi.

Pada penelitian ini, gejala autokorelasi dideteksi dengan menggunakan uji Durbin Watson atau DW-statistic. Kriteria pengambilan keputusan adalah jika du $\leq \mathrm{DW} \leq 4,00-\mathrm{du}$, berarti tidak terdapat gejala autokorelasi pada model tersebut. Hasil olah data dapat dilihat dari tabel berikut ini:

Tabel 4 Hasil Uji Autokorelasi

Model Summaryb

\begin{tabular}{|l|l|r|r|r|r|}
\hline Model & $\mathrm{R}$ & $\mathrm{R}$ Square & \multicolumn{1}{|c|}{$\begin{array}{c}\text { Adjusted R } \\
\text { Square }\end{array}$} & $\begin{array}{c}\text { Std. Error of } \\
\text { the Estimate }\end{array}$ & $\begin{array}{c}\text { Durbin- } \\
\text { Watson }\end{array}$ \\
\hline 1 &, $163^{\mathrm{a}}$ &, 027 &,- 011 &, 00849 & 1,927 \\
\hline
\end{tabular}

a. Predictors: (Constant), KA, KI

b. Dependent Variable: ROA

Sumber Hasil Penelitian, 2019 (data diolah SPSS)

Dari tabel 4 diketahui nilai DW sebesar 1,927 . Kriteria pengujian adalah $\mathrm{du} \leq \mathrm{DW} \leq 4,00-\mathrm{du}$. Nilai du sebesar 1,641, maka 1,641 $\leq 1,927 \leq$ 2,359. Artinya tidak terjadi gejala autokorelasi pada model tersebut.

Uji asumsi klasik berikutnya adalah uji heteroskedastisitas yang bertujuan untuk menguji apakah dalam model regresi terjadi ketidaksamaan variance dari residual satu pengamatan ke pengamatan yang lain. Penelitian ini menggunakan uji glejser. Apabila nilai signifikansi 
$>0,05$ maka tidak terjadi heteroskedastisitas. Hasil olah data dapat dilihat dari tabel berikut ini:

Tabel 5 Hasil Uji Heteroskedastisitas

Coefficients $^{\mathrm{a}}$

\begin{tabular}{|ll|r|r|r|r|r|}
\hline \multicolumn{2}{|l|}{ Model } & \multicolumn{2}{|c|}{ Unstandardized Coefficients } & \multicolumn{2}{c|}{$\begin{array}{c}\text { Standardized } \\
\text { Coefficients }\end{array}$} & \\
\cline { 3 - 4 } & & \multicolumn{1}{|c|}{$\mathrm{B}$} & \multicolumn{1}{|c|}{ Std. Error } & \multicolumn{1}{|c|}{ Beta } & \multicolumn{1}{c|}{ Sig. } \\
\hline 1 & (Constant) & $6,956 \mathrm{E}-6$ &, 004 & &, 002 &, 999 \\
& $\mathrm{KI}$ &, 006 &, 006 &, 144 & 1,030 &, 308 \\
& $\mathrm{KA}$ &, 001 &, 001 &, 112 &, 799 &, 428 \\
\hline
\end{tabular}

a. Dependent Variable: Abs_RES

Sumber Hasil Penelitian, 2019 (data diolah SPSS)

Dari tabel 5 diketahui nilai signifikansi sebesar 0,308 dan 0,428 untuk kedua variabel independen yang berada di atas 0,05 . Artinya tidak terjadi gejala heteroskedastisitas pada model tersebut.

\section{Pengujian Hipotesis}

\section{Uji Statistik F}

Uji $\mathrm{F}$ digunakan untuk menguji signifikansi pengaruh komisaris independen dan komite audit terhadap kinerja keuangan perusahaan perbankan yang terdaftar di Bursa Efek Indonesia secara simultan. Dengan menggunakan nilai probabilitas, jika probabilitas kurang dari 0,05 , maka terdapat pengaruh yang signifikan antara variabel independen terhadap variabel dependen secara simultan.

Tabel 6 Uji Statistik F

ANOVA $^{\mathrm{b}}$

\begin{tabular}{|ll|r|r|r|r|r|}
\hline \multicolumn{1}{|l|}{ Model } & \multicolumn{1}{c|}{$\begin{array}{c}\text { Sum of } \\
\text { Squares }\end{array}$} & \multicolumn{1}{c|}{ df } & Mean Square & \multicolumn{1}{c|}{ F } & Sig. \\
\hline 1 & Regression &, 000 & 2 &, 000 &, 713 &, $495^{\mathrm{a}}$ \\
& Residual &, 004 & 52 &, 000 & & \\
& Total &, 004 & 54 & & & \\
\hline
\end{tabular}

a. Predictors: (Constant), KA, KI

b. Dependent Variable: ROA

Sumber Hasil Penelitian, 2019 (data diolah SPSS)

Dari Tabel 6 dengan probabilitas signifikansi 0,495 yang nilainya lebih dari 0,05. Dengan demikian dapat disimpulkan bahwa tidak terdapat pengaruh yang signifikan antara variabel independen terhadap variabel dependen (kinerja keuangan) secara simultan. 


\section{Uji Statistik t}

Hasil pengujian hipotesis ini bertujuan untuk mengetahui apakah komisaris independen dan komite audit berpengaruh secara individual terhadap kinerja keuangan. Dengan menggunakan nilai probabilitas, jika probabilitas kurang dari 0,05 , maka terdapat pengaruh yang signifikan antara variabel independen terhadap variabel dependen. Pengujian ini ditunjukkan dalam Tabel 7 berikut.

Tabel 7 Uji Statistik t

Coefficients $^{\mathrm{a}}$

\begin{tabular}{|c|c|c|c|c|c|c|}
\hline \multirow{2}{*}{\multicolumn{2}{|c|}{ Model }} & \multicolumn{2}{|c|}{ Unstandardized Coefficients } & \multirow{2}{*}{$\begin{array}{c}\begin{array}{c}\text { Standardized } \\
\text { Coefficients }\end{array} \\
\text { Beta }\end{array}$} & \multirow[b]{2}{*}{$\mathrm{t}$} & \multirow[b]{2}{*}{ Sig. } \\
\hline & & $\mathrm{B}$ & Std. Error & & & \\
\hline \multirow[t]{3}{*}{1} & (Constant) &, 017 & 007 & & 2,319 &, 024 \\
\hline & $\mathrm{KI}$ &, 003 & 010 & 037 & ,265 & ,792 \\
\hline & KA &,- 002 & ,002 &,- 168 & $-1,193$ & 238 \\
\hline
\end{tabular}

a. Dependent Variable: ROA

Sumber Hasil Penelitian, 2019 (data diolah SPSS)

Berdasarkan hasil pengujian dengan regresi linier berganda yang ditunjukkan pada Tabel 7 tersebut, maka diperoleh persamaan regresi sebagai berikut.

$$
\mathrm{Y}=0,017+0,003 \mathrm{KI}-0,002 \mathrm{KA}
$$

Konstanta sebesar 0,017 menyatakan bahwa jika tidak memperhitungkan KI dan KA, maka kemungkinan kinerja keuangan perusahaan adalah sebesar 0,017 .

Secara parsial, kedua variabel independen yang dimasukkan ke dalam model regresi tidak ada variabel yang berpengaruh signifikan terhadap kinerja keuangan perusahaan.

\section{Pembahasan}

\section{Pengaruh KI terhadap Kinerja Keuangan}

Hasil pengujian pada Tabel 7 menunjukkan bahwa variabel KI tidak berpengaruh signifikan terhadap kinerja keuangan. Hal ini dilihat dari nilai $t_{\text {hitung }}$ sebesar 0,265 yang dibandingkan dengan $t_{\text {tabel }}(d f=52, \alpha=0,05)$ adalah sebesar 2,007. Oleh karena penelitian ini diuji 2 arah maka titik kritis penerimaan Ho berada antara -2,007 sampai 2,007. Dengan demikian karena $t_{\text {hitung }}<t_{\text {tabel }}$ di mana $0,265<2,007$ dan probabilitas yang diperoleh sebesar 0,792 yang lebih besar dari 0,05 $(\alpha)$ maka Ha ditolak. Angka koefisien regresi sebesar 0,003 mempunyai arti bahwa setiap penambahan 
1 komisaris independen, maka kinerja keuangan akan naik sebesar 0,003 dengan asumsi variabel lain dianggap konstan. Hasil penelitian ini tidak konsisten dengan penelitian Arifani (2013) yang menunjukkan bahwa KI berpengaruh positif signifikan terhadap kinerja keuangan. Hal ini mengindikasikan bahwa dengan ditunjuknya komisaris independen pada RUPS, akan secara langsung memberikan pengawasan terhadap direksi dalam pelaksanaan kebijakan-kebijakan yang telah dibuat untuk mencapai tujuan perusahaan, sehingga semakin meningkatkan kinerja keuangan perusahaan, sedangkan Tertius (2015) menyatakan bahwa KI berpengaruh negatif signifikan terhadap kinerja keuangan yang mengindikasikan KI yang semakin sedikitlah yang dapat mempengaruhi kinerja keuangan. Akan tetapi, hasil penelitian ini mendukung hasil penelitian Hartono (2014) yang memperoleh hasil bahwa KI tidak berpengaruh signifikan terhadap kinerja keuangan. Hal yang dapat menjelaskan dari temuan ini adalah fenomena struktur kepemilikan perusahaan perbankan di Indonesia masih sangat terkonsentrasi, penunjukkan komisaris independen tidak didasarkan pada kompetensi dan profesionalisme melainkan faktor kedekatan dengan perusahaan atau sebagai jabatan penghormatan. Hal ini akan membuat komisaris independen tidak independen lagi dalam menjalankan tugasnya. Selain itu ada kemungkinan keberadaan dewan komisaris independen dalam perusahaan perbankan dilakukan bukan untuk menegakkan good corporate governance tetapi hanya pemenuhan regulasi saja karena terdapat peraturan PBI No 8/14/PBI/2006 yang mewajibkan perbankan mempunyai jumlah komisaris independen minimal.

\section{Pengaruh KA terhadap Kinerja Keuangan}

Hasil pengujian pada Tabel 7 menunjukkan bahwa variabel KA tidak berpengaruh signifikan terhadap kinerja keuangan. Hal ini dilihat dari nilai $t_{\text {hitung }}$ sebesar $-1,193$ yang dibandingkan dengan $t_{\text {tabel }}(\mathrm{df}=52, \alpha=0,05)$ adalah sebesar 2,007. Oleh karena penelitian ini diuji 2 arah maka titik kritis penerimaan Ho berada antara -2,007 sampai 2,007. Dengan demikian karena $t_{\text {hitung }}<\mathrm{t}_{\text {tabel }}$ di mana $-1,193<2,007$ dan probabilitas yang diperoleh sebesar 0,238 yang lebih besar dari 0,05 ( $\alpha$ ) maka Ha ditolak. Angka koefisien regresi sebesar -0,002 mempunyai arti bahwa setiap penambahan 1 komite audit, maka kinerja keuangan akan turun sebesar 0,002. Hasil penelitian ini tidak konsisten dengan penelitian Arifani (2013) yang menunjukkan bahwa KA berpengaruh positif signifikan terhadap kinerja keuangan. Hal ini mengindikasikan bahwa dengan dibentuknya komite audit mampu untuk mengawasi manajemen dalam meningkatkan kinerja 
keuangannya. Akan tetapi, hasil penelitian ini mendukung penelitian Hartono (2014) yang menyatakan bahwa KA tidak berpengaruh signifikan terhadap kinerja keuangan. Peraturan Bapepam LK No. IX.1.5 mewajibkan perusahaan go public memiliki minimal 3 orang komite audit, sehingga dimungkinkan pengangkatan komite audit dalam perusahaan perbankan didasarkan pada regulasi saja tetapi tidak didasarkan pada kebutuhan perusahaan. Selain itu terindikasi bahwa pembentukan komite audit sebatas untuk pemenuhan ketentuan formal.

\section{KESIMPULAN DAN SARAN \\ Kesimpulan}

Dari hasil penelitian analisis dan uji hipotesis yang telah dilakukan, peneliti mengambil kesimpulan baik secara simultan maupun parsial, KA dan KI tidak berpengaruh signifikan terhadap kinerja keuangan pada perusahaan perbankan yang terdaftar di BEI pada tahun 2016-2017.

\section{Saran}

Dari kesimpulan yang telah diuraikan diatas, maka peneliti memiliki beberapa saran sebagai berikut:

a. Agar peneliti selanjutnya dapat menambah sampel perusahaan yang diteliti, jadi bukan hanya perbankan saja.

b. Agar peneliti selanjutnya menambah periode pengamatan.

c. Agar peneliti selanjutnya meneliti varibel lainnya yang memungkinkan memiliki pengaruh.

\section{DAFTAR PUSTAKA}

Arifani, Rizky. 2013. "Pengaruh Good Corporate Governance Terhadap Kinerja Keuangan Perusahaan (Studi pada Perusahaan yang Tercatat di Bursa Efek Indonesia)". Universitas Brawijaya, Malang. Boediono, Gideon Setyo Budiwitjaksono. 2005. "Kualitas Laba: Studi Pengaruh Mekanisme Corporate Governance dan Dampak Manajemen Laba dengan Menggunakan Analisis Jalur”. Simposium Nasional Akuntansi VIII. Solo.

Brigham, E. F., M. C. Erhardt. 2005. Financial Management Theory and Practice, 11th Edition, Ohio: South Western.

Deegan, Craig. 2004. Financial Accounting Theory. Australia: McGrawHill Australia Pty Limited. 
Hartono, Daniel Felimanto. 2014. "Pengaruh Good Corporate Governance terhadap Kinerja Keuangan Perusahaan Perbankan". Jurnal Dinamika Akuntansi Keuangan dan Perbankan". Vol.3, No.2.

Manik, T. 2011. "Analisis pengaruh kepemilikan manajemen, komisaris independen, komite audit, umur perusahaan terhadap kinerja keuangan (studi empiris perusahaan property dan real estate di BEI)". JEMI, Vol.2, No.2.

OECD. 2004. The OECD Principles of Corporate Governance. France: Organization for Economic Co-operation and Development (OECD) Publications Service.

Pandya, H. 2011. "Corporate Governance Structure and Financial Performance of Selected Indian Banks". Journal of Management and Public Policy, Vol.2, No.2.

Prasinta, D. 2012. "Pengaruh Good Corporate Governance terhadap Kinerja Keuangan”. Accounting Analysis Journal, Vol.2, No.1.

Sekaredi, Sawitri. 2011. "Pengaruh Corporate Governance Terhadap Kinerja Keuangan Perusahaan”. Fakultas Ekonomi Universitas Diponegoro, Semarang.

Syamsuddin, Lukman. 2009. Manajemen Keuangan Perusahaan. Edisi Baru. Penerbit PT. Rajagrafindo Persada, Jakarta.

Tertius, M. A., Yulius J. G. 2015. "Pengaruh Good Corporate Governance terhadap Kinerja Perusahaan pada Sektor Keuangan". Business Accounting Review, Vol.3, No.1.

Veno, Andri. 2015. "Pengaruh Good Corporate Governance terhadap Kinerja Perusahaan pada Perusahaan Manufaktur Go Public". Benefit Jurnal Manajemen dan Bisnis, Vol. 19, No.1. 